\title{
The Influence of Alkyl Substitution Pattern in Thiophene Copolymers on Composite Fullerene Solar Cell Performance
}

Barry C. Thompson, Bumjoon J. Kim, David F. Kavulak, Kevin Sivula, Clayton Mauldin, and Jean M. J. Fréchet*

Materials Sciences Division, Lawrence Berkeley National Laboratory, Berkeley, CA 94720, and

College of Chemistry, University of California, Berkeley, CA 94720-1460.

\section{Supporting Information.}

General. All chemicals were purchased from Aldrich and used without further purification unless stated otherwise. All reactions were performed under nitrogen in glassware that had been flame dried under vacuum. All compounds were characterized by ${ }^{1} \mathrm{H}$ NMR (400 MHz) and ${ }^{13} \mathrm{C}$ NMR (75 MHz) on a Bruker AVB 400 or AVQ 400. Highresolution mass spectra and elemental analysis (CHNS) was performed at the University of California, Berkeley Department of chemistry analytical services. Polymer ${ }^{1} \mathrm{H}$ NMR (500 MHz) were obtained on Bruker DRX 500. For polymer molecular weight determination, polymer samples were dissolved in HPLC grade dichlorobenzene at a concentration of $1 \mathrm{mg} / \mathrm{ml}$ and stirred overnight at room temperature prior to filtering through a $0.2 \mu \mathrm{m}$ PVDF filter and SEC was performed using HPLC grade dichlorobenzene at a flow rate of $0.8 \mu \mathrm{L} / \mathrm{min}$ on two $300 \times 8 \mathrm{~mm}$ linear S SDV, 5 micron 
columns (Polymer Standards Services, USA Inc.) at $70{ }^{\circ} \mathrm{C}$ using a Waters (Milford, MA) 2690 separation module and a Waters 410 differential refractometer to monitor samples via RI. The instrument was calibrated vs. polystyrene standards $(1,050-135,000 \mathrm{~g} / \mathrm{mol})$ and data was analyzed using Millenium 3.2 software.

Cyclic voltammograms were collected using a Solartron 1285 potentiostat under the control of CorrWare II software. A standard three electrode cell based on a Pt button working electrode, a silver wire pseudo reference electrode (calibrated vs. $\mathrm{Fc} / \mathrm{Fc}^{+}$), and a Pt wire counter electrode was purged with nitrogen and maintained under a nitrogen atmosphere during all measurements. Acetonitrile was distilled over $\mathrm{CaH}_{2}$ prior to use and tetrabutyl ammonium hexafluorophosphate $(0.1 \mathrm{M})$ was used as the supporting electrolyte. Polymer films were drop cast onto a Pt button working electrode from a 1\% (w/w) chloroform solution and dried under nitrogen prior to measurement.

UV-Visible absorption spectra were obtained using a Carey 50 Conc UV-Visible spectrophotometer. For thin film measurements polymers were spin coated onto untreated glass slides from chlorobenzene solution $(10 \mathrm{mg} / \mathrm{ml})$. A model P6700 Spincoater was used to spin coat the films at $1500 \mathrm{rpm}$ for $60 \mathrm{~s}$.

Polymer mobility was measured using a diode configuration of ITO/PEDOT:PSS/Polymer/Al in the space charge limited current regime. At sufficient potential the conduction of charges in the device can be described by

$$
J_{S C L C}=\frac{9}{8} \varepsilon_{R} \varepsilon_{0} \mu \frac{V^{2}}{L^{3}}
$$

where $\varepsilon_{0}$ is the permittivity of space, $\varepsilon_{R}$ is the dielectric of the polymer (assumed to be 3 ), $\mu$ is the mobility of the majority charge carriers, $V$ is the potential across the device $(V=$ $V_{\text {applied }}-V_{\mathrm{bi}}-V_{\mathrm{r}}$ ), and $L$ is the polymer layer thickness. The series and contact resistance 
of the device (13-21 $\Omega$ ) was measured using a blank (ITO/PEDOT/Al) and the voltage drop due to this resistance $\left(V_{\mathrm{r}}\right)$ was subtracted from the applied voltage. The built-in voltage $\left(V_{\mathrm{bi}}\right)$, which is based on the relative work function difference of the two electrodes, was also subtracted from the applied voltage. The built-in voltage can be determined from the transition between the Ohmic region and the SCL region and is found to be about $1 \mathrm{~V}$.

OFET devices were fabricated on low resistivity n-type silicon wafers, using 1000 $\AA$ thermally grown $\mathrm{SiO}_{2}$ treated with fluorooctyltrichlorosilane (FOTS) as the dielectric. FOTS coated substrates were prepared using an ASMT MVD100 Molecular Vapor Deposition System. The active semiconducting layer was applied by spin-casting 2-3 $\mathrm{mg} / \mathrm{mL}$ solutions in anhydrous chloroform at $2000 \mathrm{rpm}$. The films were then annealed at $100{ }^{\circ} \mathrm{C}$ for 20 minutes. For top contact devices, gold contacts were patterned on top of the films using various shadow masks giving channel lengths from 5 to $40 \mu \mathrm{m}$ and widths from 200 to $400 \mu \mathrm{m}$.

The electrical measurements were performed in a nitrogen atmosphere using an Agilent 4156C Precision Semiconductor Parameter Analyzer. All devices were tested as p-type OFETs in the accumulation regime and saturation mobilities were calculated using the equation, $\mu=\mathrm{gm}^{2} / 2 \mathrm{I}_{\mathrm{D}} \mathrm{C}_{\mathrm{ox}}(\mathrm{W} / \mathrm{L})$, where $\mathrm{g}_{\mathrm{m}}=$ transconductance, $\mathrm{I}_{\mathrm{D}}=$ current measured at the drain electrode, $\mathrm{C}_{\mathrm{ox}}=$ capacitance of the insulator, $\mathrm{W}=$ width of the electrodes, and $\mathrm{L}=$ channel length.

Photovoltaic Devices: Indium-doped tin oxide (ITO)-coated glass substrates were obtained from Thin Film Devices, Inc. The $150 \mathrm{~nm}$ sputtered ITO pattern had a resistivity of $10 \Omega / \square$. The substrates were subjected to ultrasonication for $20 \mathrm{~min}$ in acetone, and 
then $2 \%$ Helmanex soap in water for $20 \mathrm{~min}$, followed by extensive rinsing with deionized water and ultrasonication in deionized water and then 2-propanol. The substrates were then dried under a stream of air. Then a filtered ( $1 \mu \mathrm{m}$ glass) dispersion of PEDOT:PSS in water (Baytron-PH500) was applied immediately afterward by spin coating at $4000 \mathrm{RPM}$ for $60 \mathrm{~s}$, affording a $50 \mathrm{~nm}$ layer after baking for $10 \mathrm{mins}$ at $140{ }^{\circ} \mathrm{C}$. All procedures after this point were performed in an inert-atmosphere glovebox. Solutions of Polymer:PCBM were prepared in chlorobenzene or chloroform and were stirred at $\sim 70^{\circ} \mathrm{C}$ for $24 \mathrm{hrs}$ to ensure complete dissolution. Immediately prior to deposition, the solutions were passed though $0.45 \mu \mathrm{m}$ PTFE syringe filters. The blend solution was applied to the substrate and spun at $1500 \mathrm{RPM}$ for $60 \mathrm{~s}$. The substrates were then placed in a resistive-heating evaporation chamber and held under vacuum $\left(10^{-7}\right.$ torr $)$ for $8 \mathrm{~h}$ before evaporating $100 \mathrm{~nm}$ of $\mathrm{Al}$ through a shadow mask at a rate of $0.1-0.3 \mathrm{~nm} / \mathrm{s}$ while rotating the substrates at approximately $1 \mathrm{~Hz}$ to ensure even electrode deposition. The configuration of the shadow mask afforded eight independent devices on each substrate. The mechanical removal of part of the organic layer allowed contact with the ITO, and adding conductive paste to the removed area to ensure electrical contact completed the device. Annealing was performed after Al deposition on a temperaturecontrolled hotplate. Devices were left to cool to RT before testing. Testing of the devices was performed under an argon atmosphere with an oriel xenon arc lamp with an AM $1.5 \mathrm{G}$ solar filter. I-V behavior was measured with a Keithly 236 SMU. Eight devices were averaged for each condition.

Transmission Electron Microscopy (TEM): Transmission electron microscope images were obtained using a FEI TECNAI $\mathrm{G}^{2}$ with a $200 \mathrm{kV}$ accelerating voltage. 
Samples were prepared by spin-casting films from either chloroform or chlorobenzene as used for device measurement on to freshly cleaved $\mathrm{NaCl}$ single crystal substrates at 1500 $\mathrm{rpm}$ for $60 \mathrm{~s}$. The films were floated onto water and placed onto a 600 mesh copper TEM grid (Electron Microscopy Science, Inc.).

\section{Synthesis.}

2-Bromo-3-dodecylthiophene (1): In $50 \mathrm{ml}$ of glacial acetic acid, $9.898 \mathrm{~g}(39.3$ mmol) of 3-dodecylthiophene was dissolved at room temperature and then treated with $7.01 \mathrm{~g}(39.4 \mathrm{mmol})$ of freshly recrystalized NBS added as a solid in one portion. The reaction was then heated to $45^{\circ} \mathrm{C}$ for 30 minutes and then cooled to room temperature. The reaction mixture was then poured into $150 \mathrm{ml}$ water and $150 \mathrm{ml}$ ether and the aqueous layer was separated and discarded. The aqueous layer was then washed with $2 \mathrm{M}$ $\mathrm{NaOH}(\mathrm{x} 5)$ and then washed with water before drying over $\mathrm{MgSO}_{4}$. Rotary evaporation followed by distillation $\left(130{ }^{\circ} \mathrm{C}, 90 \mathrm{mTorr}\right)$ gave the product as a clear oil. ${ }^{1} \mathrm{H}$ NMR (400 $\left.\mathrm{MHz}, \mathrm{CDCl}_{3}\right) \delta 7.17(\mathrm{~d}, 1 \mathrm{H}), 6.79(\mathrm{~d}, 1 \mathrm{H}), 2.55(\mathrm{t}, 2 \mathrm{H}), 1.55(\mathrm{~m}, 2 \mathrm{H}), 1.31-1.26$ (br m, 18H), $0.88(\mathrm{t}, 3 \mathrm{H}) .{ }^{13} \mathrm{C} \mathrm{NMR}\left(75 \mathrm{MHz}, \mathrm{CDCl}_{3}\right) \delta 141.9,128.2,125.1,108.8,31.9,29.7-$ 29.2 multiplet, 22.7, 14.1. Values are consistent with those reported in the literature. ${ }^{1}$

2-bromo-5-(5-bromo-4-dodecylthiophen-2-yl)-3-dodecylthiophene (2). In a $150 \mathrm{ml}$ 3-neck flask, $141 \mathrm{mg} \mathrm{Pd}(\mathrm{PhCN})_{2} \mathrm{Cl}_{2}(0.37 \mathrm{mmol}, 3 \mathrm{~mol} \%)$ was dissolved in $60 \mathrm{ml}$ DMSO and bubbled with nitrogen for 20 minutes. Then, $4.04 \mathrm{~g}(12.2 \mathrm{mmol})$ of 1 was added followed by $3.10 \mathrm{~g} \mathrm{AgF}(24.4 \mathrm{mmol})$. The reaction was stirred for $48 \mathrm{~h}$ at $45^{\circ} \mathrm{C}$. The reaction mixture was then cooled and poured into water acidified with $\mathrm{HCl}$ and 
extracted with ether, followed by multiple washes with water. After drying with $\mathrm{MgSO}_{4}$ and rotary evaporation, the crude product was subjected to column chromatography with hexanes to yield $1.30 \mathrm{~g}(32 \%)$ of the product as a yellow solid (mp $\left.56-57{ }^{\circ} \mathrm{C}\right) .{ }^{1} \mathrm{H}$ NMR $\left(400 \mathrm{MHz}, \mathrm{CDCl}_{3}\right) \delta 6.76(\mathrm{~s}, 2 \mathrm{H}), 2.50(\mathrm{t}, 4 \mathrm{H}), 1.54(\mathrm{~m}, 4 \mathrm{H}), 1.31-1.25(\mathrm{br} \mathrm{m}, 36 \mathrm{H}), 0.87$ $(\mathrm{t}, 6 \mathrm{H}) .{ }^{13} \mathrm{C}$ NMR $\left(75 \mathrm{MHz}, \mathrm{CDCl}_{3}\right) \delta 142.9,136.1,124.4,107.8,31.9,29.7-29.2$ multiplet, 22.7, 14.1. HRMS calcd for $\mathrm{C}_{32} \mathrm{H}_{52} \mathrm{Br}_{2} \mathrm{~S}_{2}\left(\mathrm{M}^{+}\right)$, 658.1877; found 658.1877. Anal. calcd for $\mathrm{C}_{32} \mathrm{H}_{52} \mathrm{Br}_{2} \mathrm{~S}_{2}$ : C, 58.17; H, 7.93; S, 9.71. Found: C, 57.99; H, 7.94; S, 9.69 .

\section{2-(trimethylstannyl)-5-(5-(trimethylstannyl)thiophen-2-yl)thiophene}

(3).

Compound 3 was prepared according to the literature ${ }^{2}$ (mp 90-92 ${ }^{\circ} \mathrm{C}$ ). ${ }^{1} \mathrm{H}$ NMR (400 $\left.\mathrm{MHz}, \mathrm{CDCl}_{3}\right) \delta 7.27(\mathrm{~d}, 2 \mathrm{H}), 7.07(\mathrm{~d}, 2 \mathrm{H}), 0.37(\mathrm{~s}, 18 \mathrm{H}) .{ }^{13} \mathrm{C}$ NMR $\left(75 \mathrm{MHz}, \mathrm{CDCl}_{3}\right)$ $\delta$ 143.0, 137.0, 135.8, 124.7, -8.3. HRMS calcd for $\mathrm{C}_{14} \mathrm{H}_{22} \mathrm{~S}_{2} \mathrm{Sn}_{2}\left(\mathrm{M}^{+}\right)$, 491.9201; found 491.9195. Anal. calcd for $\mathrm{C}_{14} \mathrm{H}_{22} \mathrm{~S}_{2} \mathrm{Sn}_{2}$ : C, 34.19; H, 4.51; $\mathrm{S}, 13.04$. Found: C, 34.30; H, 4.66; S, 12.74 .

PQT-DD. In a mixture of $40 \mathrm{ml}$ of toluene and $10 \mathrm{ml}$ of DMF, $0.303 \mathrm{~g}$ of $2(0.46$ mmol) and $0.227 \mathrm{~g}$ of $3(0.46 \mathrm{mmol})$ were dissolved and degassed by bubbling with nitrogen. Then $40 \mathrm{mg}$ of $\mathrm{Pd}\left(\mathrm{PPh}_{3}\right)_{4}(5 \mathrm{~mol} \%)$ was added and the reaction was heated to $100{ }^{\circ} \mathrm{C}$ for $24 \mathrm{~h}$. The bright red solution that resulted was cooled to room temperature and precipitated into $500 \mathrm{ml}$ of methanol. After filtration, the resulting solid was further purified by Soxhlet extraction with methanol and hexanes and then taken up in chloroform and isolated by precipitation into methanol to give $0.270 \mathrm{~g}$ of polymer $(89 \%)$. 
${ }^{1} \mathrm{H}$ NMR (500 MHz, dichlorobenzene-d $\left.{ }_{4}\right) \delta 7.00$ (br d, 5.4H), 2.74 (br, 4H), 1.66 (br, 4H), 1.33-1.24 (br, 36H), 0.78 (br, 6H). SEC Analysis (DCB vs. PS): $M_{\mathrm{n}}=19,810 \mathrm{~g} / \mathrm{mol} ; M_{\mathrm{w}}=$ $41,815 \mathrm{~g} / \mathrm{mol}$; PDI $=2.11$.

P3DDT-co-T. Compound 1 (1.05 g, $3.2 \mathrm{mmol})$ was dissolved in $30 \mathrm{ml}$ of THF and treated with 0.98 eq of LDA in $15 \mathrm{ml}$ of THF at $-78{ }^{\circ} \mathrm{C}$. In a separate flask, 2bromothiophene $(0.50 \mathrm{~g}, 3.1 \mathrm{mmol})$ in $30 \mathrm{ml}$ of THF was treated with 0.99 eq of LDA in $15 \mathrm{ml}$ of $\mathrm{THF}$ at $-78^{\circ} \mathrm{C}$. The two solutions were stirred for $1 \mathrm{~h}$ at $-78{ }^{\circ} \mathrm{C}$ and then $0.48 \mathrm{~g}$ of $\mathrm{ZnCl}_{2}(3.5 \mathrm{mmol})$ was added to each flask and the reaction mixtures were stirred at -78 ${ }^{\circ} \mathrm{C}$ for 20 minutes and then warmed to room temperature for $1 \mathrm{~h}$. The solution containing 2-bromothiophene was then added to the solution containing compound $\mathbf{1}$ via cannula and then $75 \mathrm{mg}$ of $\mathrm{Ni}(\mathrm{dppp}) \mathrm{Cl}_{2}$ was added in portion and the resulting solution was stirred overnight at room temperature. The opaque dark purple solution that resulted was precipitated into $500 \mathrm{ml}$ of methanol. After filtration, the resulting solid was further purified by Soxhlet extraction with methanol and hexanes and then taken up in chloroform and isolated by precipitation into methanol to give $0.900 \mathrm{~g}$ of polymer (84\%). ${ }^{1} \mathrm{H}$ NMR (500 MHz, dichlorobenzene-d 4 ) $\delta 7.01$ (br m, 3.8H), 2.78 (br, 2H), 1.67 (br, 2H), 1.33-1.24 (br, 18H), 0.78 (br, 3H). SEC Analysis (DCB vs. PS): $M_{\mathrm{n}}=19,425 \mathrm{~g} / \mathrm{mol}$; $M_{\mathrm{w}}=38,706 \mathrm{~g} / \mathrm{mol} ; \mathrm{PDI}=1.99$. 
Supporting Figures.

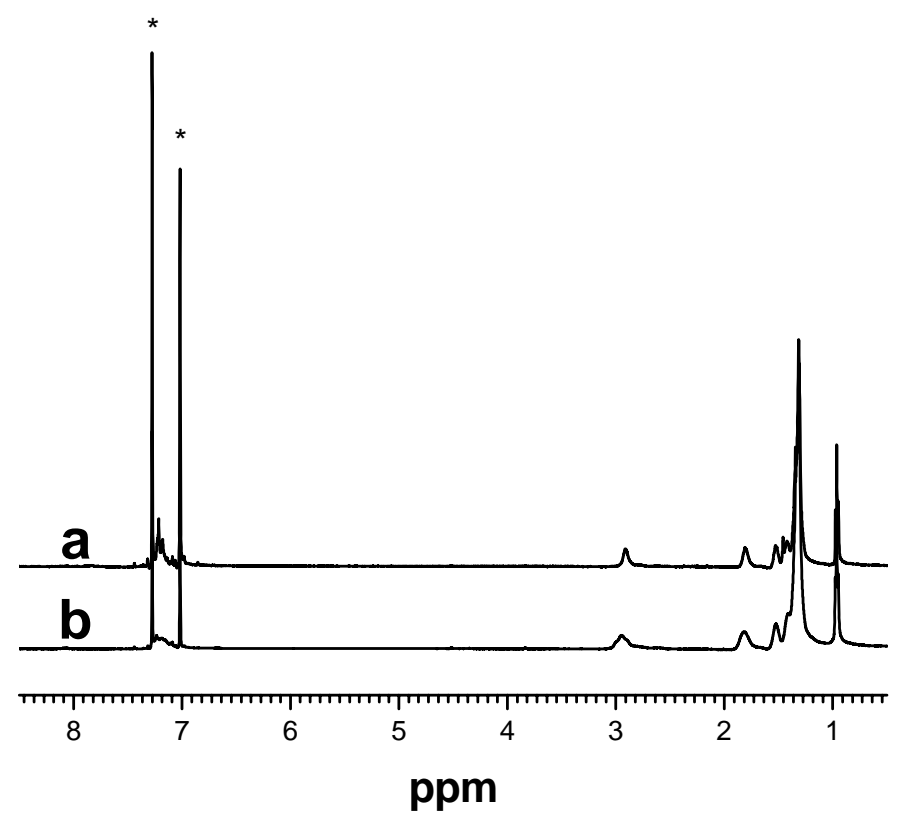

Figure S1. ${ }^{1} \mathrm{H}$ NMR for PQT-DD (a) and P3DDT-co-T (b). Asterisks (*) indicate peaks residual to dichlorobenzene- $\mathrm{d}_{4}$. 


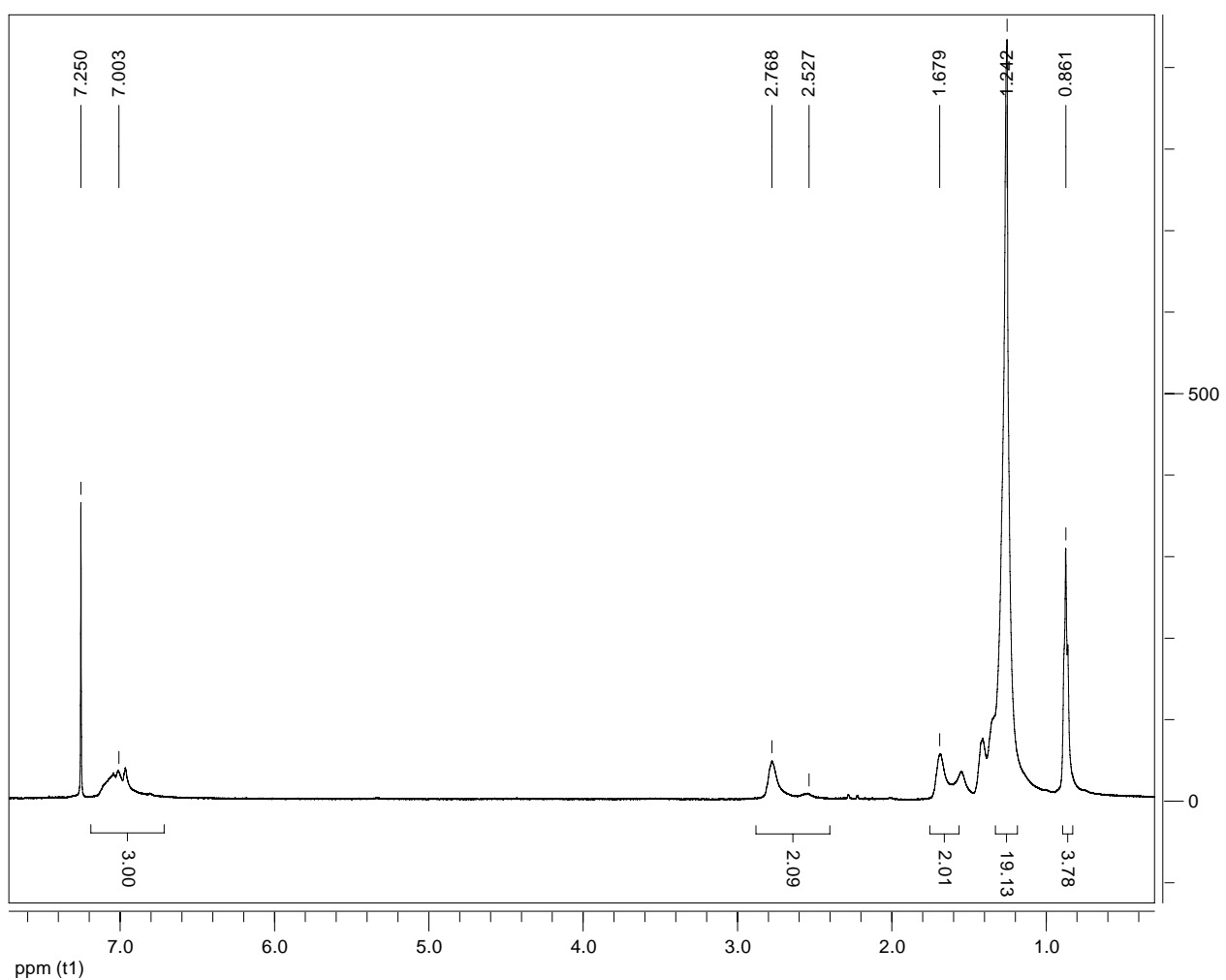

Figure S2. ${ }^{1} \mathrm{H}$ NMR of P3DDT-co-T taken in $\mathrm{CDCl}_{3}$ at room temperature. Integration of peaks at aryl protons $(7.00 \mathrm{ppm})$ and benzylic protons $(2.79$ and $2.53 \mathrm{ppm})$ show the $\sim 3: 2$ ratio indicative of a 1:1 3-dodecylthiophene:thiophene copolymer. 


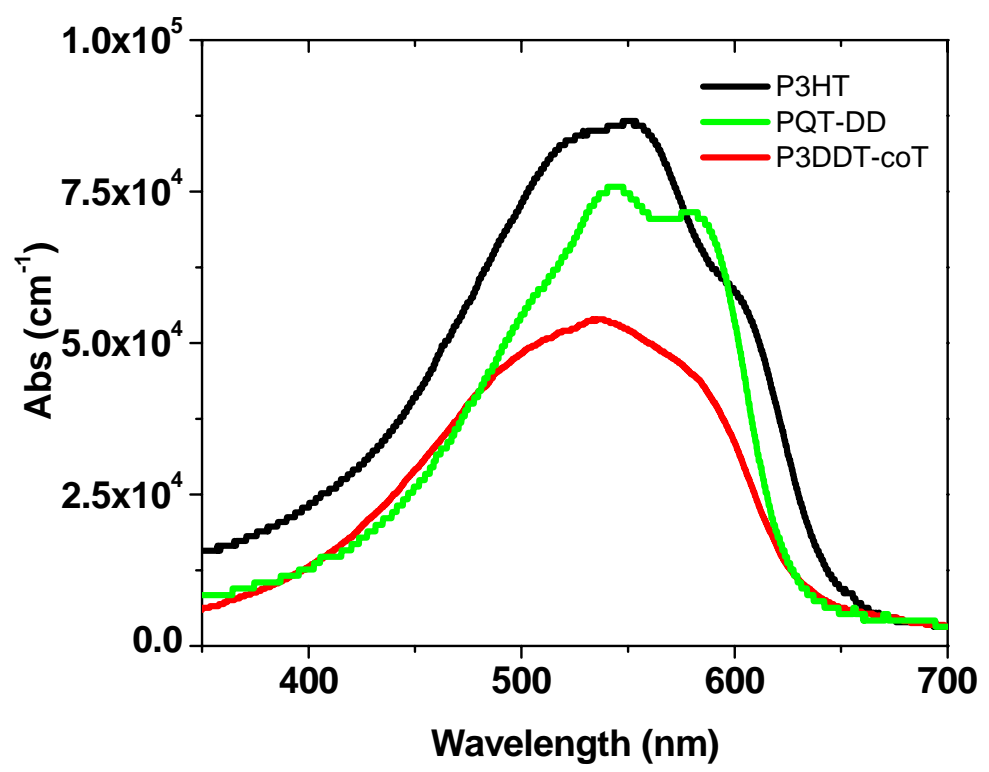

Figure S3. Thin film absorption spectra of polymers PQT-DD and P3DDT-co-T plotted relative to thin film absorption coefficient. P3HT is shown for reference. For P3HT $\lambda_{\max }$ $=551 \mathrm{~nm}\left(8.7 \times 10^{4} \mathrm{~cm}^{-1}\right)$, for PQT-DD $\lambda_{\max }=544 \mathrm{~nm}\left(7.6 \times 10^{4} \mathrm{~cm}^{-1}\right)$, and for P3DDTco-T $\lambda_{\max }=533 \mathrm{~nm}\left(5.4 \times 10^{4} \mathrm{~cm}^{-1}\right)$.

Table S1. Electrochemical Properties of Copolymers.

\begin{tabular}{|l|l|l|l|l|l|}
\hline Polymer & $\begin{array}{l}\text { Oxidation } \\
\text { vs Fc/Fc } \\
(\mathrm{V})^{1}\end{array}$ & $\begin{array}{l}\text { Reduction vs } \\
\mathrm{Fc}^{1} \mathrm{Fc}^{+}(\mathrm{V})\end{array}$ & HOMO (eV) & LUMO (eV) & Eg (eV) \\
\hline PQT-DD & 0.25 & -1.71 & -5.35 & -3.39 & 1.95 \\
\hline P3DDT-co-T & 0.35 & -1.69 & -5.45 & -3.41 & 2.04 \\
\hline P3HT & 0.17 & -2.02 & -5.27 & -3.08 & 2.19 \\
\hline
\end{tabular}

${ }_{2}^{1}$ All electrochemical values are reported as onsets.

${ }^{2}$ All electrochemical values are converted to vacuum based on the relation that the $\mathrm{Fc} / \mathrm{Fc}^{+}$ redox couple lies $5.1 \mathrm{eV}$ below the vacuum level. 

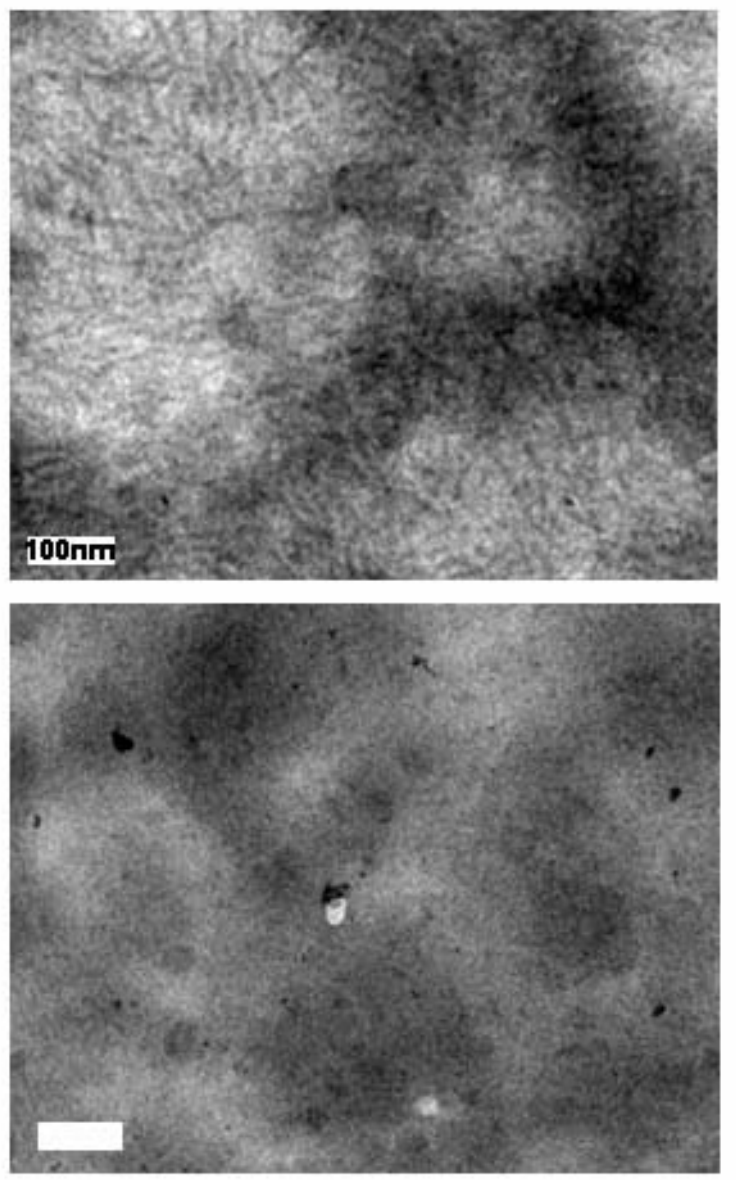

Figure S4. TEM images for pristine films of PQT-DD (top) and P3DDT-co-T (bottom). Scale bars represent $100 \mathrm{~nm}$ in both images. 

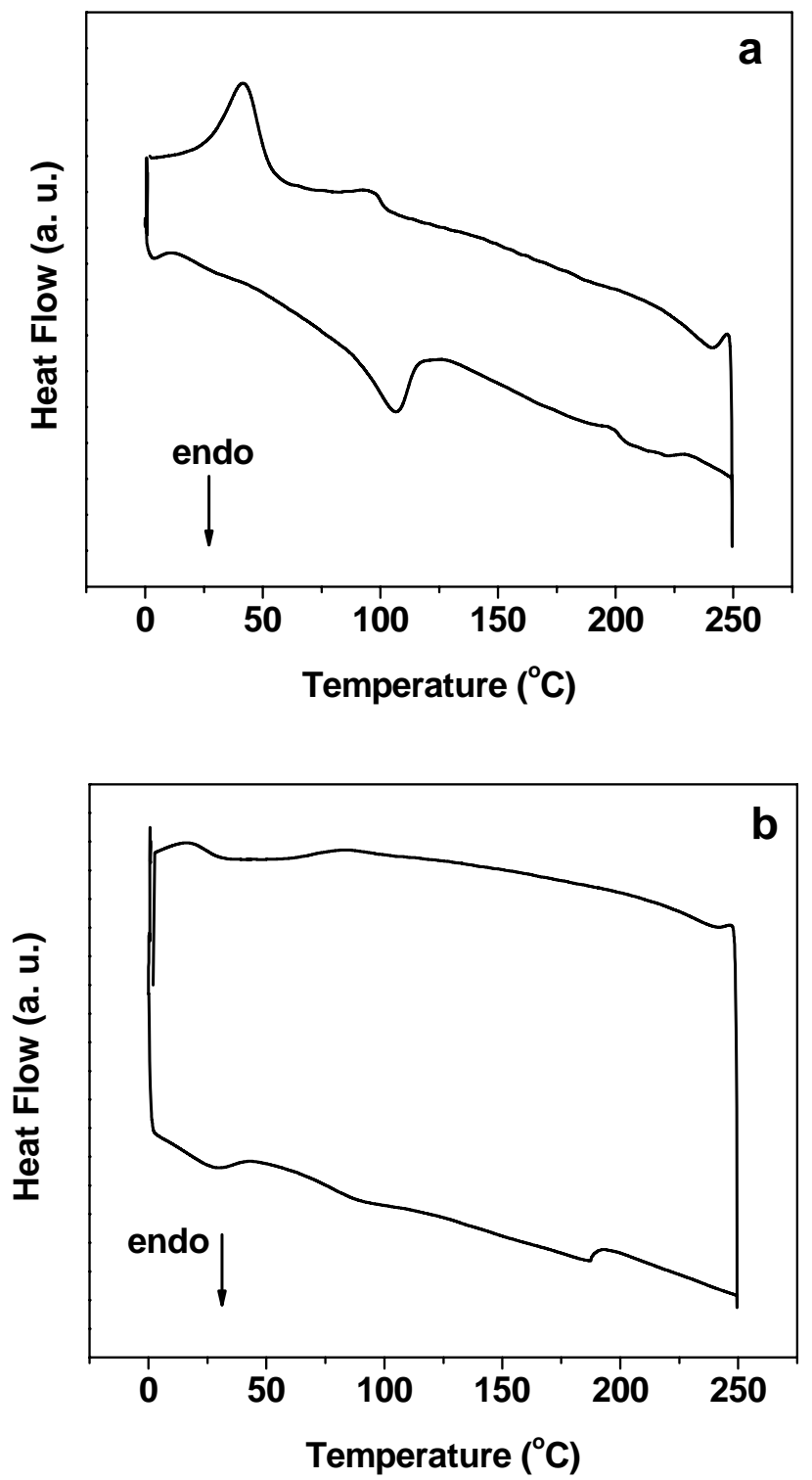

Figure S5. Second cycles of DSC for PQT-DD (a) and P3DDT-co-T (b). 

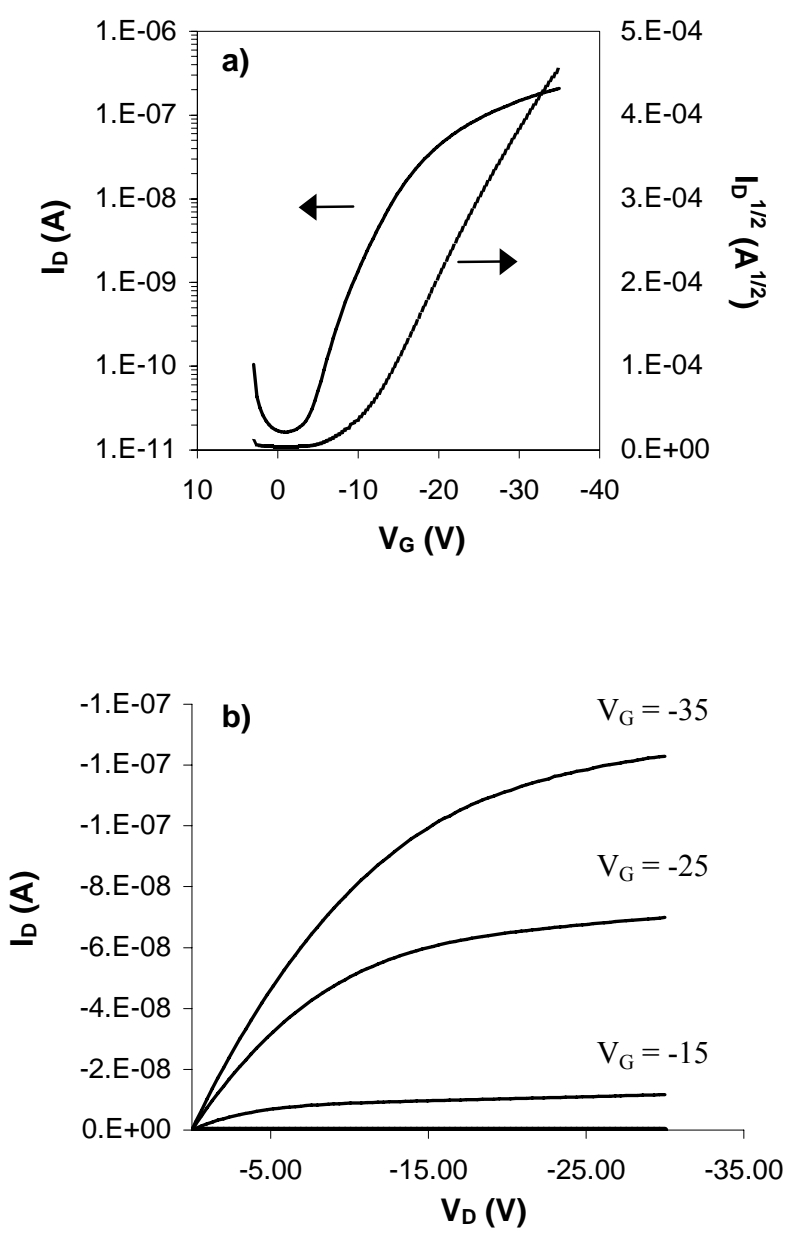

Figure S6. I-V curves shown for an OFET of P3DD-coT with $\mathrm{W}=400 \mu \mathrm{m}$ and $\mathrm{L}=40$ $\mu \mathrm{m}$. Plots of a) $I_{D}$ and $I_{D}{ }^{1 / 2}$ vs. $V_{G}$ at $V D=-30 \mathrm{~V}$ and b) $I_{D}$ vs. $V_{D}$ at at varying $V_{G}$. In transistors fabricated using the above method, P3DD-coT gave an average saturation charge mobility of $0.001 \pm 0.0007 \mathrm{~cm}^{2} / \mathrm{V} \cdot \mathrm{s}$ and an average on $/$ off ratio of $10^{4}$. 


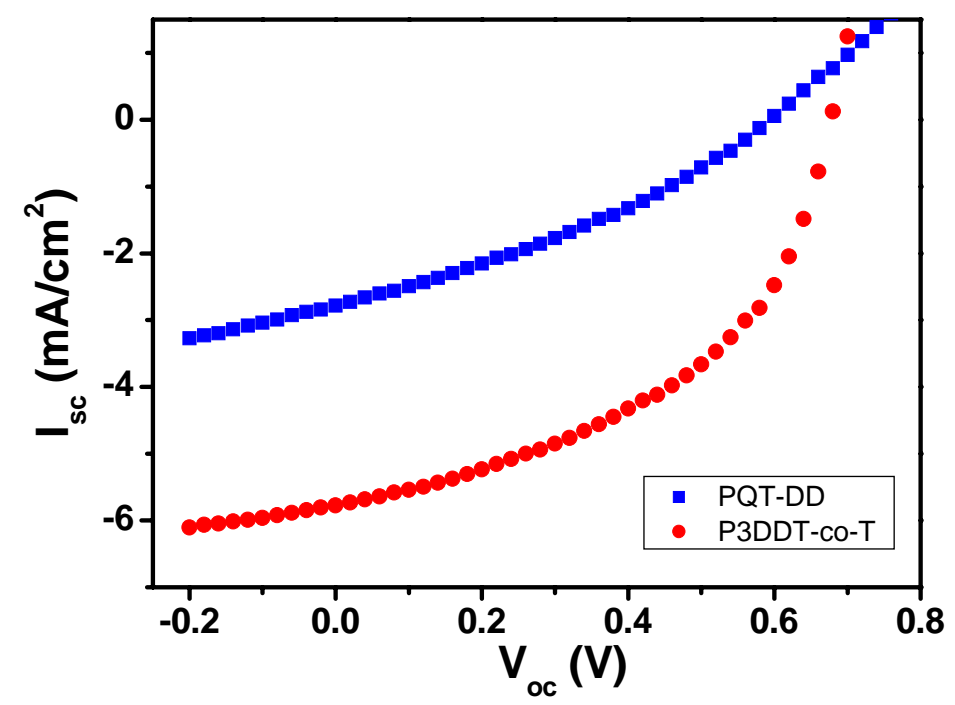

Figure S7. Current-voltage characteristics for the best performing devices with each polymer. For, P3DDT-co-T $\eta=1.84 \%, \mathrm{~J}_{\mathrm{sc}}=-5.77 \mathrm{~mA} / \mathrm{cm}^{2}, \mathrm{~V}_{\mathrm{oc}}=0.68 \mathrm{~V}$, and $\mathrm{FF}=$ 0.47. For PQT-DD, $\eta=0.54 \%, \mathrm{~J}_{\mathrm{sc}}=-2.78 \mathrm{~mA} / \mathrm{cm}^{2}, \mathrm{~V}_{\mathrm{oc}}=0.59 \mathrm{~V}$, and $\mathrm{FF}=0.33$. 

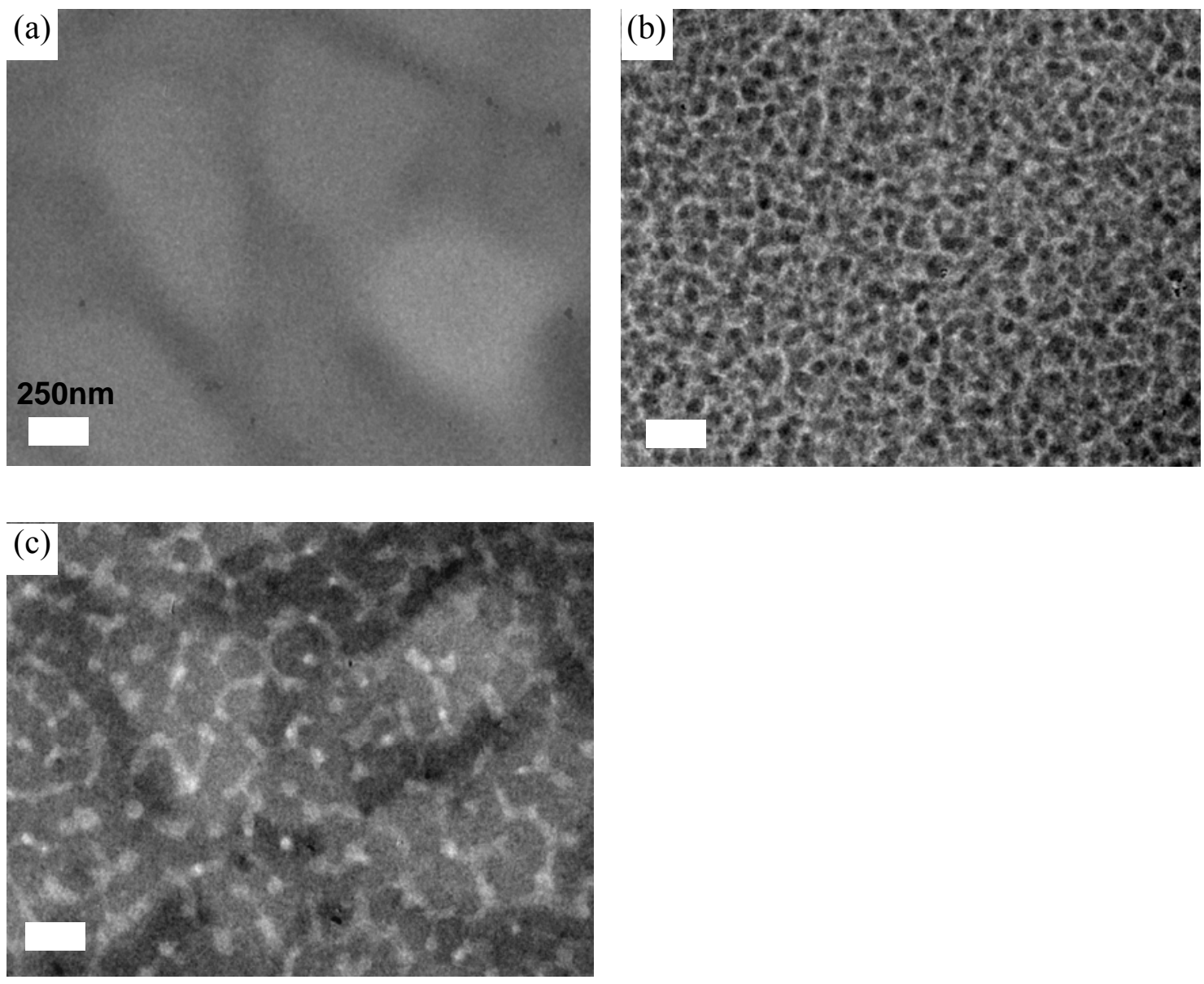

Figure S8. Additional TEM images showing the progression of morphology with composition. (a) Weight ratio of P3DDT-co-T to PCBM $=50: 50$, (b) $30: 70$ and (c) 10 : 90 . All scale bars correspond to $250 \mathrm{~nm}$.

\footnotetext{
${ }^{1}$ McCullough, R. D.; Lowe, R. D.; Jayaraman, M.; Anderson, D. L. J. Org. Chem. 1993, 58, 904-912.

${ }^{2}$ Murphy, A. R.; Liu, J.; Luscombe, C.; Kavulak, D.; Fréchet, J. M. J.; Kline, R. J.; McGehee, M. D. Chem. Mater. 2005, 17, 4892-4899.
} 